\title{
Biological Control of Wheat Root Diseases by the CLP-Producing Strain Pseudomonas fluorescens HC1-07
}

\author{
Ming-Ming Yang, Shan-Shan Wen, Dmitri V. Mavrodi, Olga V. Mavrodi, \\ Diter von Wettstein, Linda S. Thomashow, Jian-Hua Guo, and David M. Weller
}

First and seventh authors: Department of Plant Pathology, College of Plant Protection, Nanjing Agricultural University, Engineering Center of Bioresource Pesticide in Jiangsu Province, Key Laboratory of Monitoring and Management of Crop Diseases and Pest Insects, Ministry of Agriculture, Nanjing, 210095, China; first and fourth authors: Department of Plant Pathology, Washington State University, Pullman 99164-6430; second and fifth authors: Department of Crop and Soil Sciences, Washington State University, Pullman 99164-6420; third author: Department of Biological Sciences, The University of Southern Mississippi, Hattiesburg 39406; and sixth and eighth authors: United States Department of Agriculture-Agricultural Research Service, Root Disease and Biological Control Research Unit, Pullman, WA 99164-6420.

Accepted for publication 14 October 2013.

\section{ABSTRACT}

Yang, M.-M., Wen, S.-S., Mavrodi, D. V., Mavrodi, O. V., von Wettstein, D., Thomashow, L. S., Guo, J.-H., and Weller, D. M. 2014. Biological control of wheat root diseases by the CLP-producing strain Pseudomonas fluorescens HC1-07. Phytopathology 104:248-256.

Pseudomonas fluorescens HC1-07, previously isolated from the phyllosphere of wheat grown in Hebei province, China, suppresses the soilborne disease of wheat take-all, caused by Gaeumannomyces graminis var. tritici. We report here that strain $\mathrm{HC} 1-07$ also suppresses Rhizoctonia root rot of wheat caused by Rhizoctonia solani AG-8. Strain HC1-07 produced a cyclic lipopeptide (CLP) with a molecular weight of $1,126.42$ based on analysis by electrospray ionization mass spectrometry. Extracted CLP inhibited the growth of G. graminis var. tritici and $R$. solani in vitro. To determine the role of this CLP in biological control, plasposon mutagenesis was used to generate two nonproducing mutants, $\mathrm{HC} 1-07 \mathrm{viscB}$ and $\mathrm{HC} 1-07 \mathrm{prtR} 2$. Analysis of regions flanking plasposon insertions in $\mathrm{HC} 1-07 \mathrm{prtR} 2$ and $\mathrm{HC} 1-07 \mathrm{viscB}$ revealed that the inactivated genes were similar to $p r t R$ and $v i s c B$, respectively, of the well-described biocontrol strain $P$. fluorescens SBW25 that produces the CLP viscosin. Both genes in HC1-07 were required for the production of the viscosinlike CLP. The two mutants were less inhibitory to G. graminis var. tritici and $R$. solani in vitro and reduced in ability to suppress take-all. $\mathrm{HC} 1-$ 07viscB but not HC-07prtR2 was reduced in ability to suppress Rhizoctonia root rot. In addition to CLP production, prtR also played a role in protease production.

Additional keyword: biosurfactant.
Take-all and Rhizoctonia root rot, caused by the soilborne necrotrophic fungal pathogens Gaeumannomyces graminis var. tritici and Rhizoctonia solani AG-8, respectively, cause severe damage to irrigated and dryland wheat and barley $(6,48,49)$ in the Inland Pacific Northwest (PNW) of the United States. Take-all is considered one of the most important root diseases of wheat in the United States and worldwide and Rhizoctonia root rot is a severe problem in Australian cereal production; however, surprisingly, in the United States, root rot caused by $R$. solani AG-8 seems to be confined to the PNW. The incidence and severity of Rhizoctonia root rot is greatly exacerbated by reduced tillage, and this disease is the primary cause for the slow adoption of no-till (direct seeding), which is needed to reduce soil erosion in the PNW. Because of the lack of genetic resistance and the fact that fungicides are effective only during the seedling phase of these diseases, biological control by either introduced or indigenous agents and sustainable management practices represent the best options for long-term control $(6,47,48,61,62)$. A disease decline phenomenon

Corresponding authors: J.-H. Guo; E-mail address: jhguo@njau.edu.cn D. M. Weller; E-mail address: wellerd@wsu.edu and david.weller@ars.usda.gov

* The $\boldsymbol{e}$-Xtra logo stands for "electronic extra" and indicates that the online version contains four supplemental figures. Figure 1 appears in color online.

http://dx.doi.org/10.1094/PHYTO-05-13-0142-R

This article is in the public domain and not copyrightable. It may be freely reprinted with customary crediting of the source. The American Phytopathological Society, 2014 resulting in soils suppressive to either take-all $(62,63)$ or Rhizoctonia root rot $(36,54)$ has been described and many growers have utilized this highly sustainable natural form of biocontrol to manage these diseases. For example, Cook (6) reported that 0.8 million ha of PNW farmland are now cropped continuously or nearly so to rotations of spring wheat, spring barley, and winter wheat, and these crops suffer little damage from take-all owing to take-all decline (TAD) (6). Several promising biocontrol agents capable of suppressing take-all and Rhizoctonia root rot have been described and tested in the PNW and elsewhere. In particular, antibiotic-producing strains of grampositive Bacillus spp. and gram-negative Pseudomonas spp. have proved to be effective as seed treatments in controlling $G$. graminis var. tritici or $R$. solani AG-8 under field conditions in the PNW $(7,28,51,61)$.

Several groups of antibiotics are known to mediate the suppression of fungal phytopathogens by fluorescent Pseudomonas spp. (20,21,35), and antibiotics of special interest have included phenazines $(37,38,58)$, pyoluteorin $(20,25)$, pyrrolnitrin $(20,24)$, and 2,4-diacetylphloroglucinol $(40,62)$, as well as biosurfactants like cyclic lipopeptides (CLPs) and rhamnolipids (27,45,52, 53,57). CLPs are versatile molecules with antimicrobial, cytotoxic, and surfactant properties produced by many different bacterial genera, including plant-associated Pseudomonas spp. $(8,52)$. The potential of CLPs produced by Pseudomonas spp. to suppress diverse phytopathogens is documented in several different studies. For example, Tran et al. (59) demonstrated that the CLP massetolide A from Pseudomonas fluorescens SS101 
played an important role in suppression of Phytophthora infestans, whereas viscosin contributed to the control of broccoli head rot by Pseudomonas fluorescens PfA7B (4). The CLP viscosinamide produced by Pseudomonas sp. DR54 triggered the encystment of Pythium zoospores and reduced the mycelial growth of $R$. solani and Pythium ultimum (43). Amphisin played an important role in the surface motility of Pseudomonas sp. strain DSS73, allowing efficient containment of root-infecting plant-pathogenic fungi $(44,45)$. Lipodepsipeptides produced by the pathogen Pseudomonas syringae pv. syringae mediate the antagonism of this organism towards several phytopathogenic fungi (19). van den Broek et al. (60) reported that a lipopeptide was likely involved in the suppression of take-all of wheat by Pseudomonas sp. PCL1171. Finally, CLPs produced by Pseudomonas sp. CMR12a acted synergistically with phenazines in the control of Pythium and Rhizoctonia spp. on bean $(9,50)$.

The biosynthesis and regulation of CLPs in Pseudomonas spp. has been well studied $(8,52)$, with biosynthesis governed by nonribosomal peptide synthetases (NRPSs) encoded by large gene clusters and composed of modules, one for each amino acid incorporated in the oligopeptide. Each module consists of several conserved domains, responsible for recognition, activation, transport, and binding of the amino acid to the peptide chain. A special thioesterase domain in the last module coordinates cyclization and release of the peptide product $(8,18,52)$. In addition, many studies have focused on the genetic regulation of CLP production in pseudomonads. The well-known GacS/GacA two-component regulatory system appears to serve as a master switch for CLP production as it does for other secondary metabolites (10,16). Furthermore, acyl-homoserine lactone quorum sensing is involved in the regulation of some of the CLPs produced by Pseudomonas spp. $(10,17)$. LuxR type transcriptional regulator genes, such as salA and $s y r G$, were also found to play a role in CLP biosynthesis regulation $(3,12,15)$. DnaK, a member of the Hsp70 heat-shock protein family, is involved in regulation of CLP synthesis in P. putida (16).

This study focused on the biocontrol agent $P$. fluorescens strain $\mathrm{HC} 1-07$, isolated from the phyllosphere of wheat grown in a field in Hebei province. In this region of China, there is a long history of cereal production; take-all is a chronic problem and little is known about the communities of wheat-associated, diseasesuppressive bacteria (64). Strain HC1-07 was selected for further study because it was representative of one of the morphotypes of fluorescent pseudomonads isolated from wheat. This strain suppressed take-all of wheat caused by isolates of G. graminis var. tritici from both China and the PNW of the United States (64).

This study was part of an ongoing collaboration to select and develop biocontrol agents for use in Chinese agriculture, identify mechanisms of action, and determine the relatedness of the Chinese agents to others worldwide. Our specific aim was to determine the role of CLPs in the suppression G. graminis var. tritici and $R$. solani AG-8 by strain HC1-07. A CLP produced by strain $\mathrm{HC1-07}$ was isolated and identified as a viscosin-like compound and two genes, viscB and prtR, involved in the CLP production were identified by random plasposon mutagenesis. We characterized the two CLP-deficient mutants and showed them to be less effective at controlling take-all compared with the wildtype strain; however, only the mutant disrupted in $v i s c B$ was less suppressive of Rhizoctonia root rot.

\section{MATERIALS AND METHODS}

Microorganisms, media, and culture conditions. Bacteria and fungi used in this study are listed in Table 1. A spontaneous rifampicin-resistant derivative of $P$. fluorescens $\mathrm{HC1-07}$ (64) with growth characteristics similar to those of the wild-type strain was used throughout this study. P. fluorescens and Escherichia coli were routinely cultured in King's medium B (KMB) agar and broth (29) and Luria-Bertani (LB) broth (1), respectively. When needed, antibiotics were supplemented in the following concentrations: chloramphenicol $\left(13 \mu \mathrm{g} \mathrm{m}^{-1}\right)$, tetracycline $\left(25 \mu \mathrm{g} \mathrm{ml}^{-1}\right)$, ampicillin $\left(40 \mu \mathrm{g} \mathrm{ml}^{-1}\right)$, cycloheximide $\left(100 \mu \mathrm{g} \mathrm{ml}^{-1}\right)$, and rifampicin $\left(100 \mu \mathrm{g} \mathrm{ml}^{-1}\right)$ (Table 1). Bacteria were stored at $-80^{\circ} \mathrm{C}$ in LB broth supplemented with $40 \%$ (vol/vol) glycerol.

G. graminis var. tritici isolates LD5, ARS-A1, and R3-111a-1 (32) and $R$. solani AG-8 isolate C-1 (26) were grown on one-fifthstrength potato dextrose agar (1/5 PDA) prepared from either fresh potato and adjusted to $\mathrm{pH} 6.5$ as described by Yang et al. (64) or commercial potato dextrose broth (PDB) (Becton Dickinson, Sparks, MD). To prepare homemade PDA, diced potato tubers $(200 \mathrm{~g})$ were cooked in water in a microwave for $15 \mathrm{~min}$ and the resultant broth was strained and brought to 1 liter, supplemented with dextrose (20 g) and agar (15 g), and then autoclaved (64). All fungi were stored at $4^{\circ} \mathrm{C}$ on $1 / 5$ PDA made from fresh potato and amended with rifampicin $\left(100 \mu \mathrm{g} \mathrm{ml} \mathrm{m}^{-1}\right)$ (31).

Generation of CLP-deficient mutants by transposon mutagenesis. CLP-deficient mutants of HC1-07rif were generated by subjecting the strain to mutagenesis with plasposon TnMod-OTc' (13). The plasposon was delivered into HC1-07rif using biparental matings with $E$. coli $\mathrm{S} 17-1$ ( $\lambda$ pir). The transposants were selected on LB amended with tetracycline and rifampicin, then screened for the loss of biosurfactant production by the dropcollapse assay (14), which measures the ability of a bacterial metabolite to reduce surface tension of a liquid spotted on a piece of Parafilm.

The number of TnMod-OTc' copies in genomes of the biosurfactant-deficient mutants was analyzed by Southern blot hybridization. Briefly, genomic DNA was isolated using a GenElute Bacterial Genomic DNA kit (Sigma-Aldrich, St. Louis) following the manufacturer's instructions. The extracted DNA was dissolved in $100 \mu \mathrm{l}$ of sterile deionized water and stored at $-20^{\circ} \mathrm{C}$. Genomic DNA of the mutants was digested to completion with endonucleases EcoRV and PstI. The DNA fragments were

TABLE 1. Bacteria and plasmids used in this study

\begin{tabular}{|c|c|c|}
\hline Organism, strain, or plasmid & Genotype, characteristics ${ }^{\mathrm{z}}$ & Source/reference \\
\hline Pseudomonas fluorescens $\mathrm{HC1}-07$ & $\mathrm{CLP}^{+}$ & 64 \\
\hline HC1-07rif & $\mathrm{Rif}^{\mathrm{T}} \mathrm{CLP}^{+}$ & This study \\
\hline HC1-07viscB & Rif $^{\mathrm{r}}$ viscB::TnMod CLP- & This study \\
\hline HC1-07prtR2 & $\operatorname{Rif}^{\mathrm{T}} \operatorname{prtR}:: \operatorname{Tn} M o d$ CLP $^{-}$ & This study \\
\hline HC1-07prtR2-1 & $\operatorname{Rif}^{\mathrm{C}} \mathrm{CLP}^{+}$complemented mutant; prtR2 ${ }^{+}$ & This study \\
\hline \multicolumn{3}{|l|}{ Escherichia coli } \\
\hline $\mathrm{S} 17-1(\lambda$ pir $)$ & thi pro hsdR hsdM recA rpsL RP4-2 Tet $:: M u \operatorname{Kan}^{\mathrm{r}}:: \operatorname{Tn} 7 \lambda$ pir & Laboratory collection \\
\hline p TnMod-OTc' & $\mathrm{Tn} M o d ;$ oriR; $\mathrm{Tc}^{\mathrm{r}}$ & 13 \\
\hline $\mathrm{pEX} 18 \mathrm{Gm}$ & Gene replacement vector; $\mathrm{Gm}^{\mathrm{r}}$ oriT $\mathrm{sacB}$ & Laboratory collection \\
\hline
\end{tabular}


separated on a $1 \%$ agarose gel and transferred onto a Hybond $\mathrm{N}$ nylon membrane (GE Healthcare, Piscataway, NJ) using standard techniques (1). The hybridization probe contained a 515-bp fragment of the tetracycline resistance gene and was obtained by amplification of $\mathrm{p}$ TnMod-OTc' with primers Tet_UP and Tet_LOW (38). The probe was labeled with digoxigenin (DIG) using DIG High Prime DNA Labeling and Detection Starter Kit (Roche Diagnostics GmbH, Germany).

The hybridization conditions included prehybridization $(1.5 \mathrm{~h}$ at $\left.65^{\circ} \mathrm{C}\right)$ and hybridization $\left(12 \mathrm{~h}\right.$ at $\left.65^{\circ} \mathrm{C}\right)$ steps followed by stringency washes (twice each for 5 min with $2 \times \mathrm{SSC}$ [1× SSC is $0.15 \mathrm{M} \mathrm{NaCl}$ plus $0.015 \mathrm{M}$ sodium citrate] and $0.1 \%$ sodium dodecyl sulfate [SDS] at room temperature, and twice each for 30 min with $0.1 \times \mathrm{SSC}$ and $0.1 \% \mathrm{SDS}$ at $65^{\circ} \mathrm{C}$ ). The hybridized DIGlabeled probe was immunodetected according to the protocol provided by Roche.

To characterize regions flanking plasposon insertion sites, $1 \mu \mathrm{g}$ of total genomic DNA was digested with EcoRI (does not cut within TnMod-OTc') and the resultant fragments were selfligated under conditions favorable for intramolecular reactions. The ligation mixture $(2 \mu \mathrm{l})$ was transformed into $E$. coli $\mathrm{DH} 5 \alpha$ by electroporation and clones containing the resultant TnMod-OTc'based plasmids were selected by plating on LB amended with tetracycline. Regions of the HC1-07 genome flanking the TnMod$\mathrm{OTc}^{\prime}$ insertion sites were sequenced using the plasposon-based oligonucleotide primers Ori (5'-GGCCTTTTGCTCACATGT-3') and Tet (5'-TCAATTCTTGCGGAGAAC-3').

Genetic complementation of CLP-deficient mutants. The CLP-deficient mutants $\mathrm{HC1}-07 \mathrm{viscB}$ and $\mathrm{HC1}-07$ prtR2 were complemented as follows. The $1.0-\mathrm{kb}$ fragment of viscB corresponding to the TnMod-OTc' integration site in $\mathrm{HC1}-07 \mathrm{viscB}$ was amplified by polymerase chain reaction (PCR) with primers viscB1 (5'-GGAGCAACTGGTACAGGCGT-3') and viscB2 (5'GCACTTCGTAGGTAGTGGCGT-3') using DNA of HC1-07 as a template. Similarly, the $1.0-\mathrm{kb}$ fragment of prtR that corresponds to the plasposon integration site in HC1-07prtR2 was amplified by PCR with primers PrtR1 (5'-AGCTCAACACCGAGCAGC-3') and PrtR2 (5'-TATCGGCAGCCAGGTGTT-3'), again using DNA of $\mathrm{HC} 1-07$ as a template. Both amplicons were cloned into pEX18Gm and the resultant plasmids were single-pass sequenced to ensure the absence of mutations. The plasmids were mobilized into HC1-07viscB or HC1-07prtR2, respectively, using biparental matings with $E$. coli S17-1 ( $\lambda$ pir). Single crossover events were recovered on LB medium supplemented with gentamicin, and several gentamicin-resistant colonies were streaked on LB amended with $5 \%$ sucrose to select for double crossovers. The reversion to wild-type $v i s c B$ and $p r t R$ alleles and the loss of the pEX18Gm backbone were confirmed by PCR with primer sets viscB1/viscB2, PrtR1/PrtR2, and GM_UP/GM_LOW (38). The complemented mutants were also assayed by the drop collapse assay for the gain of function to produce CLP.

Phenotypic profiling. Swimming and swarming motility were visualized by spot-inoculating bacteria on standard succinate medium (12) supplemented with $0.25 \%$ (wt/vol) (swimming motility assays) and $0.6 \%$ (wt/vol) (swarming motility assays) of agar. The inoculated plates were incubated overnight at $28^{\circ} \mathrm{C}$. Biofilm formation was assessed in untreated polystyrene flatbottom 96-well plates (Greiner Bio-One, Monroe, NC) prefilled with $200 \mu \mathrm{l}$ of M63 medium, as described by O'Toole and Kolter (46) and Dubern et al. (17). Exoprotease production was assessed according to Lawrence et al. (34) by inoculating $20 \mu \mathrm{l}$ of a 24-hold bacterial culture in wells cut in $2.5 \%$ skim milk agar using a 4-mm cork borer. The inoculated plates were incubated for $48 \mathrm{~h}$ at $28^{\circ} \mathrm{C}$ and the diameter of the halo was measured. The production of siderophores was determined by measuring orange haloes after 2 days of growth at $28^{\circ} \mathrm{C}$ on CAS (chrome azurol S) agar (54). All assays were repeated twice, with three replicates per strain.
In vitro inhibition of fungal pathogens by strain $\mathrm{HC1-07}$ and its isogenic derivatives. The capacity of $\mathrm{HC} 1-07$ and its isogenic mutant and recombinant derivatives to inhibit the growth of G. graminis var. tritici isolates LD5, ARS-A1, and R3-111a-1 and $R$. solani AG- 8 isolate C-1 was tested on PDA made from fresh potato, as described by Yang et al. (64). Aliquots $(5 \mu \mathrm{l})$ from overnight cultures of each strain grown in $\mathrm{KMB}$ broth were spotted $1 \mathrm{~cm}$ from the edge of a Petri dish containing homemade PDA and allowed to soak into the agar. A $0.5-\mathrm{cm}$ plug from the leading edge of a 7-day-old 1/5 PDA culture of G. graminis var. tritici or 5-day-old culture of $R$. solani was placed in the center of the plate. The inoculated plates were incubated at $24^{\circ} \mathrm{C}$ and scored after 5 or 7 days by measuring the distance between the edges of the bacterial colony and the fungal mycelium. Each plate consisted of three isolates and a control that was not inoculated. All assays were repeated twice and each isolate was replicated three times. Inhibition was expressed relative to a noninoculated control.

Isolation and characterization of CLP. To extract the CLP, strain $\mathrm{HC} 1-07$ and its mutant derivatives were grown on $\mathrm{KMB}$ agar for $48 \mathrm{~h}$ at $28^{\circ} \mathrm{C}$. The bacterial cells were scraped from the agar surface and washed twice in $20 \mathrm{ml}$ of sterile deionized water. The supernatant was passed through a membrane filter $(0.22-\mu \mathrm{m}$ pore size), acidified to $\mathrm{pH} 2.0$ with $9 \% \mathrm{HCl}$, and kept on ice for $1 \mathrm{~h}$. The precipitate was collected by centrifugation $(30 \mathrm{~min}$ at $6,000 \mathrm{rpm}$ and $4^{\circ} \mathrm{C}$ ) and washed twice with sterile deionized water ( $\mathrm{pH} 2.0)$ (14). The precipitate was resuspended in $20 \mathrm{ml}$ of sterile deionized water ( $\mathrm{pH}$ 8.0) and lyophilized (Supermodul Yo-220; Thermo Savant, NY). The lyophilized extract was stored at $-20^{\circ} \mathrm{C}$. The lyophilized sample was analyzed by electrospray ionization mass spectrometry (ESI-MS) by the State Key Laboratory of Coordination Chemistry, Nanjing University, essentially as described by Hong et al. (23). Briefly, an aliquot of the biosurfactant sample was dissolved in methanol to obtain a stock solution of $1 \mathrm{mg} \mathrm{ml}^{-1}$. Freshly prepared working solutions were made by diluting the stock solution with methanol to 10 or $15 \mu \mathrm{g} \mathrm{m} \mathrm{m}^{-1}$. ESI mass spectra were recorded using a Finnigan MAT LCQ ion-trap mass spectrometer (Thermo Finnigan, San Jose, CA) in the positive ionization mode. Samples were injected at a flow rate of $2 \mu \mathrm{min}^{-1}$. Source voltage and capillary voltage were $5.0 \mathrm{kV}$ and $17 \mathrm{~V}$ in positive ion mode. Capillary temperature and sheath gas $\left(\mathrm{N}^{2}\right)$ flow were set at 290 and 12 arbitrary units, respectively, in both scan modes. Data were acquired in positive MS total ion scan mode (mass scan range of $\mathrm{m} / \mathrm{z} 200$ to 2,000).

Effect of CLPs on the growth of $G$. graminis var. tritici and R. solani AG-8. The effect of the CLP on growth of the $G$. graminis var. tritici isolates and $R$. solani AG-8 C-1 was examined as follows. The CLP was extracted from strain HC1-07 as described above. A 5-mm-diameter plug was excised from the margin of a 7-day-old 1/5 PDA culture of $G$. graminis var. tritici or 5-day-old culture of $R$. solani AG-8 and placed in the center of a Petri plate containing 1/5 PDA amended with the CLP at 0,10 , or $100 \mu \mathrm{g} \mathrm{ml}^{-1}$. The inoculated plates were incubated at room temperature and radial hyphal growth was measured at 5 days for $R$. solani AG-8 or 7 days for $G$. graminis var. tritici. Three replicate plates per concentration were included in the experiment and the entire experiment was repeated twice.

Treatment of wheat seed with bacteria. For greenhouse biocontrol or root colonization studies in the field, wheat seed ('Penawawa' or 'Louise') was treated with bacteria, as described by Yang et al. (64). Briefly, KMB plates were spread inoculated with the test bacterium and incubated for $48 \mathrm{~h}$ at room temperature. A $1 \%$ methyl cellulose solution (4 ml) (M-6385; SigmaAldrich) was added to the plate and the bacteria were scraped into a test tube, shaken for $30 \mathrm{~s}$, and then mixed with $5.3 \mathrm{~g}$ of wheat seed. Treated seed were dried for $2 \mathrm{~h}$ under a stream of sterile air. The final density of bacteria was $\approx 10^{7} \mathrm{CFU} \mathrm{seed}{ }^{-1}$. For field studies, larger amounts of seed were treated using the same proportions. 
Preparation of oat-kernel inoculum. Inoculum of $G$. graminis var. tritici and $R$. solani AG-8 was prepared essentially as described by Kwak et al. (31). Briefly, $250 \mathrm{ml}$ of untreated whole oat grains plus $350 \mathrm{ml}$ of water were combined in a 1-liter flask and autoclaved for 90 min on each of two successive days. Sterile oat grains were inoculated with agar disks of G. graminis var. tritici isolate LD5 or $R$. solani AG-8 isolate C-1. After 3 to 4 weeks of growth at room temperature, the contents of each jar were air dried and stored at $4^{\circ} \mathrm{C}$.

Biological control assays. A tube assay previously described by Yang et al. (64) was used to determine the biocontrol activity of bacteria against take-all or Rhizoctonia root rot. Briefly, plastic tubes $(2.5 \mathrm{~cm}$ in diameter and $16.5 \mathrm{~cm}$ long) were supported in a hanging position in racks $\left(200\right.$ cones rack $\left.^{-1}\right)$. The hole in the bottom of each tube was plugged with a cotton ball and the tube was then filled with a 6.5 -cm-thick column of sterile vermiculite followed by air-dried and sieved Quincy virgin soil (Shano sandy loam) (10 g). For some experiments, the soil was first pasteurized $\left(60^{\circ} \mathrm{C}\right.$ for $\left.30 \mathrm{~min}\right)$ in order to reduce the interference from other soilborne pathogens. G. graminis var. tritici or $R$. solani colonized oat-kernel inoculum was pulverized in a Waring Blender and sieved into fractions of known particle sizes. The fraction of 0.25 to $0.5 \mathrm{~mm}$ was added to the soil at 0.7 and $1.0 \%$ (wt/wt) for $G$. graminis var. tritici and $R$. solani, respectively. Three bacteriatreated wheat seed were placed on the soil surface and covered with a 1.5-cm-thick topping of vermiculite. Each tube received $10 \mathrm{ml}$ of water. The rack of tubes was incubated at 15 to $18^{\circ} \mathrm{C}$ in a 12-h cycle of light and darkness and, for the first 4 days, was covered with plastic. After the plastic was removed, each cone received $10 \mathrm{ml}$ of water two times a week and diluted $(1: 3$ [vol/vol]) Hoagland's solution (macroelements only) once a week. All treatments were replicated five times and arranged in a randomized complete block design. After 3 to 4 weeks, plants were removed from the tubes, the roots were washed free of soil, and plants were evaluated for disease severity on a scale of 0 to 8 , as previously described $(26,51)$, where $0=$ no disease evident and 8 = plants dead or nearly so. All experiments were repeated at least twice with similar results.

Rhizosphere colonization assays. Bacterial strains were tested under both controlled and field conditions for ability to colonize roots of wheat. For assays under controlled conditions, bacteria (strains HC1-07rif, HC1-07viscB, HC1-07prtR2, HC1-07viscB-1, and $\mathrm{HC} 1-07$ prtR2-1) were prepared and applied individually to Quincy virgin soil in a $1 \%$ methylcellulose suspension, as previously described $(33,39)$, to obtain $10^{4} \mathrm{CFU} \mathrm{^{-1 }}$ of soil. The actual density of each strain introduced into the soil was determined by assaying $0.5 \mathrm{~g}$ of inoculated soil, as described below. Control soils consisted of soil amended only with a $1 \%$ methylcellulose suspension. Each treatment was replicated six times with a single pot serving as a replicate. Spring wheat (Penawawa) seed were pregerminated in the dark on moistened sterile filter paper in petri dishes $(24 \mathrm{~h})$ and were sown (6 per pot) in square pots (height, $6.5 \mathrm{~cm}$; width, $7 \mathrm{~cm}$ ) containing $200 \mathrm{~g}$ of Quincy virgin soil (33) inoculated with one of the bacterial strains. Control treatments consisted of soil amended with a $1 \%$ methylcellulose suspension. Plants were grown for three successive cycles in a controlled environment chamber at 15 to $18^{\circ} \mathrm{C}$ with 12 -h photoperiod. After 2 weeks of growth (one cycle), population densities of bacteria were determined essentially as described by Mavrodi et al. (39). Briefly, for each replicate, the roots plus adhering rhizosphere soil from three individual plants were excised and assayed by first vortexing in 10 or $20 \mathrm{ml}$ of sterile water (depending on the amount of roots) followed by sonication in a water bath. Each plant was processed separately. Population densities of the introduced strains were monitored by the modified dilution endpoint method $(42,64)$. Briefly, to detect the introduced strains, the soil suspensions were serially diluted in wells of 96-well microtiter plates containing sterile water $(200 \mu \mathrm{l})$ and these dilutions were transferred to plates containing $1 / 3 \times \mathrm{KMB}$ broth supplemented with rifampicin, cycloheximide, ampicillin, and chloramphenicol $\left(1 / 3 \times \mathrm{KMB}^{+++}\right.$Rif). Population densities of total culturable heterotrophic aerobic bacteria were determined by performing the same assay in $1 / 10 \times$ tryptic soy broth supplemented with only cycloheximide $\left(1 / 10 \times \mathrm{TSB}^{+}\right)$. Plates with $1 / 3 \times$ $\mathrm{KMB}^{+++}$Rif and $1 / 10 \times \mathrm{TSB}^{+}$were incubated for 72 and $48 \mathrm{~h}$, respectively, at room temperature and an optical density at $600 \mathrm{~nm} \geq 0.1$, measured with a microplate reader, was scored as positive for growth.

A field test of the ability of strain HC1-07rif to colonize the rhizosphere of the spring wheat (Louise) grown without irrigation at the Washington State University Plant Pathology Research Farm, Pullman was conducted in 2010. As previously described (64), the plot was cultivated in the spring and fertilized with 89-25-20-10 (N-P-S-Cl), which was applied as a dry formulation and incorporated to a depth of 10 to $15 \mathrm{~cm}$. Seed furrows $(40.6$ $\mathrm{cm}$ apart) were opened mechanically to a depth of 6 to $8 \mathrm{~cm}$ and seed were hand sown and covered with $\approx 3 \mathrm{~cm}$ of soil. Treatments included strain HC1-07rif, applied at $\approx 10^{7} \mathrm{CFU}$ seed $^{-1}$ as described above, and nontreated seed as a control. Treatments were part of a larger experiment and arranged in a randomized complete block design.

Each treatment consisted of four 2.13-m-long rows and was replicated six times. Every 3 weeks, plants were sampled from three locations in a replicate by digging them with a shovel to a depth of $\approx 20 \mathrm{~cm}$, and excess soil was removed from the roots by gentle shaking. Plants from each replicate were placed in a new plastic bag, transferred to the laboratory, and immediately processed. For each replicate, the roots plus adhering rhizosphere soil from three individual plants were processed separately. The population size of introduced strain HC1-07rif and the indigenous culturable heterotrophic aerobic bacteria in the rhizosphere was detected with the dilution end-point assay, as described above.

Data analysis. Statistical analyses were performed by using appropriate parametric and nonparametric procedures with the STATISTIX 8.0 software (Analytical Software, St. Paul, MN). All population data were converted to $\log \mathrm{CFU}$ per gram (fresh weight) of root. Differences in population densities among treatments were determined by standard analysis of variance, and mean comparisons among treatments were performed by using Fisher's protected least-significant-difference test $(P=0.05)$ or the Kruskal-Wallis all-pairwise comparison test $(P=0.05)$. Data from phenotypic assays were compared by using a two-sample $t$ test or the Wilcoxon rank sum test $(P=0.05)$.

Accession numbers. The nucleotide sequences of $v i s c B$ and prt $R$ genes of $P$. fluorescens $\mathrm{HC1}-07$ were deposited in GenBank under accession numbers AFN27384.1 and AFN27386.1, respectively.

\section{RESULTS}

Isolation and characterization of biosurfactants produced by $P$. fluorescens HC1-07. Extraction of CLP from the culture supernatant of $P$. fluorescens $\mathrm{HC1-07}$ yielded a white precipitate $(\approx 90 \%$ pure) (data not shown) that was analyzed by ESI-MS. Results of the analysis revealed a major peak in the mass spectrum at $\mathrm{m} / \mathrm{z} 1,125.42[\mathrm{M}+\mathrm{H}]^{-}$, which closely matched the molecular weight of the biosurfactants viscosin, massetolide $\mathrm{F}$, or massetolide L (produced by some strains of $P$. fluorescens) (Supplemental Figure 1) (10). Amino acid analysis of the CLP (conducted by the Washington State University Laboratory for Bioanalysis \& Biotechnology, Pullman) narrowed the possibilities to massetolide $\mathrm{F}$ or viscosin (data not shown).

The CLP extracted from HC1-07 was tested for the capacity to inhibit hyphal growth of $G$. graminis var. tritici and $R$. solani. Addition of the CLP to growth media at concentrations of 10 and $100 \mu \mathrm{g} \mathrm{ml}^{-1}$ resulted in strong inhibition of both pathogens (Table 
2; Supplemental Figure 2) but G. graminis var. tritici was more sensitive to the CLP than $R$. solani. The hyphal growth of $G$. graminis var. tritici was completely inhibited by the viscosinlike CLP at $100 \mu \mathrm{g} \mathrm{ml}^{-1}$, whereas the same amount of this CLP caused only 55\% inhibition of $R$. solani (Table 2 ).

Plasposon mutagenesis and characterization of CLP-deficient mutants. To clone genes involved in the production of the CLP, P. fluorescens HC1-07 was subjected to mutagenesis with the TnMod-OTc' plasposon. As a result, in total, 390 transformants were obtained. Two of these, HC1-07viscB and HC107prtR2, failed to produce CLP, which was evident from the absence of foam formation after vigorous shaking and inability to

TABLE 2. Relative inhibition (\%) of radial hyphal growth of Gaeumannomyces graminis var. tritici and $R$. solani pathogenic isolates cultured on one-fifth-strength potato dextrose agar (1/5 PDA) amended with cyclic lipopeptide (CLP) at the indicated concentration ${ }^{\mathrm{z}}$

\begin{tabular}{lccc}
\hline & \multicolumn{3}{c}{ CLP concentration $(\mu \mathrm{g} / \mathrm{ml})$} \\
\cline { 2 - 4 } Pathogens & 0 & 10 & 100 \\
\hline G. tritici LD5 & 0 & 42.9 & 100.0 \\
G. tritici ARS-A1 & 0 & 50.0 & 100.0 \\
G. tritici R3-111a-1 & 0 & 35.0 & 100.0 \\
R. solani AG-8 & 0 & 10.0 & 55.0 \\
\hline
\end{tabular}

${ }^{\mathrm{z}}$ Data represent the mean from three replicate plates. Reduction of radial hyphal growth of the pathogens on 1/5 PDA amended with indicated concentration of CLP compared with that on the control plate (no CLP amended). lower the surface tension of water during the collapsed drop assay (Fig. 1). Southern hybridization showed that each of the two mutants contained single-transposon integration events. The mutants were further tested for the ability to swim and swarm on semisolid medium, and to produce siderophores, exoprotease, and biofilm. Results of the testing revealed that HC1-07viscB and HC1-07prtR2 were deficient in swimming and swarming motility (Table 3; Supplemental Figure 3A and B). In addition to that, HC1-07prtR2 lost the ability to secrete exoprotease at 23 and $29^{\circ} \mathrm{C}$ (Table 3; Supplemental Figure 3C), while HC1-07viscB retained the wild-type levels of exoprotease production. The production of siderophores in both mutants remained unaffected and similar to that in HC1-07 (Table 3; Supplemental Figure 3D). $\mathrm{HC1}-07 v i s c B$ and $\mathrm{HC} 1-07$ prtR2 were reduced in ability to form biofilms compared with the wild-type strain (Table 3; Fig. 1B). The genetic complementation of mutants with the corresponding wild-type DNA fragments restored the surface motility and production of exoprotease to the wild-type levels and partially restored biofilm formation (Table 3 ).

Identification of genes affected by the plasposon insertions. In order to identify genes interrupted by TnMod-OTc' in strains $\mathrm{HC1}-07$ viscB and $\mathrm{HC1}-07 \mathrm{prtR} 2$, we recovered and sequenced DNA regions flanking the plasposon insertions. Comparison of the resultant sequences against the nonredundant GenBank dataset revealed that, in $\mathrm{HC} 1-07 \mathrm{viscB}$, the plasposon insertion disrupted a gene with strong similarity $(90 \%$ identity at the amino acid level to NRPS; blastp E-value 0.0) to $v i s c B$, a gene involved

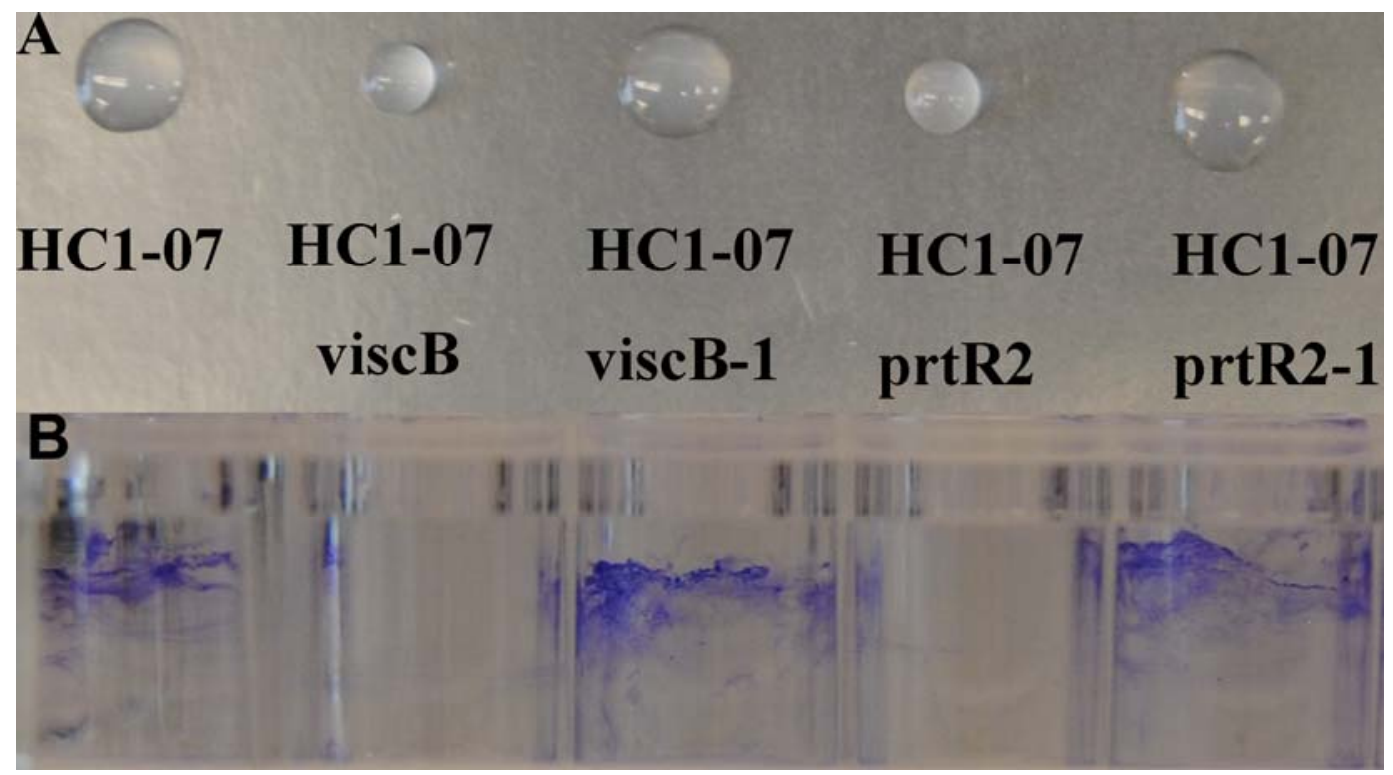

Fig. 1. Comparison of biosurfactant production and biofilm formation in Pseudomonas fluorescens HC1-07rif and its cyclic lipopeptide-deficient mutants and complemented mutant derivatives. A, Drop collapse assay with cultures of the wild-type strain HC1-07rif, two mutants (HC1-07viscB and HC1-07prtR2), and two complemented mutants (HC1-07viscB-1 and HC1-07prtR2-1). Bacterial cells grown for 2 days at $28^{\circ} \mathrm{C}$ were resuspended in sterile water, and 20- $\mu 1$ droplets were spotted on Parafilm. A flat droplet is indicative of viscosin production. B, Biofilm formation by strain HC1-07 and its mutants in polystyrene microtiter plates. Cells firmly attached to the walls of the wells were stained with $0.1 \%$ crystal violet.

TABLE 3. Phenotypes of HC1-07, cyclic lipopeptide (CLP)-deficient mutants, and complemented strains ${ }^{\mathrm{x}}$

\begin{tabular}{|c|c|c|c|c|c|c|}
\hline \multirow[b]{2}{*}{ Strain } & \multirow[b]{2}{*}{ CLP } & \multicolumn{2}{|c|}{ Production of ${ }^{\mathrm{y}}$} & \multirow[b]{2}{*}{ Biofilm formation $^{z}$} & \multirow[b]{2}{*}{ Swarming motility } & \multirow[b]{2}{*}{ Swimming motility } \\
\hline & & Exoprotease (cm) & Siderophores $(\mathrm{cm})$ & & & \\
\hline HC1-07rif & + & $0.97 \mathrm{~A}$ & $1.12 \mathrm{~A}$ & $0.35 \mathrm{~A}$ & + & + \\
\hline HC1-07 viscB & - & $0.93 \mathrm{~A}$ & $1.37 \mathrm{~A}$ & $0.05 \mathrm{~B}$ & - & - \\
\hline HC1-07 viscB-1 & + & $0.96 \mathrm{~A}$ & $1.26 \mathrm{~A}$ & $0.20 \mathrm{AB}$ & + & + \\
\hline HC1-07 prtR2 & - & ND & $1.13 \mathrm{~A}$ & $0.06 \mathrm{~B}$ & - & - \\
\hline $\mathrm{HC} 1-07$ prtR2-1 & + & $0.96 \mathrm{~A}$ & $1.18 \mathrm{~A}$ & $0.21 \mathrm{AB}$ & + & + \\
\hline
\end{tabular}

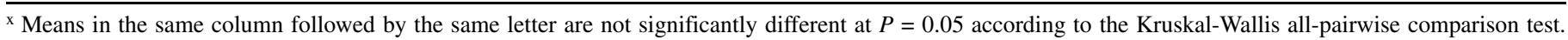

$\mathrm{ND}=$ no halo detected. HC1-07prtR2 was not included in the analysis of halo diameter.

y Halo diameter.

z Absorbance at $600 \mathrm{~nm}$. 
in the production of the biosurfactant viscosin in P. fluorescens SWB25, and closely related to NRPSs from other Pseudomonas spp. (Table 4). Collectively, this finding, along with data generated by MS and amino acid analyses, indicated that the CLP was similar to viscosin. In HC1-07prtR2, the plasposon insertion disrupted a gene encoding a transmembrane regulator with strong similarity (94\% identity at the amino acid level; blastp E-value 5e-148) to PrtR of $P$. fluorescens SWB25. Results of blast searches revealed that homologous genes were also present in other fluorescent Pseudomonas spp. (Table 5).

Impact of viscB and prtR mutations on rhizosphere colonization of HC1-07. The impact of $v i s c B$ and $p r t R$ mutations on the ability of $\mathrm{HC} 1-07$ to colonize and persist in the rhizosphere of wheat was tested under controlled conditions in a growth chamber. In the wheat cycling experiment, HC1-07rif, mutants, and complemented mutants were introduced individually into Quincy virgin soil and population sizes of each strain were determined in the wheat rhizosphere after each 2-week-long growth cycle of wheat. Of the two tested mutants, only HC1-07prtR2 was mildly but significantly impaired in the ability to persist in the wheat rhizosphere (Fig. 2A). In cycle 2, the population size of HC1-07prtR2 was $\approx 1 \log$ unit lower than that of the wild-type parent and significantly less than the other strains. Complementation of the prtR mutation restored plant colonization to the wild-type levels. In cycle 3 , the same trend was seen, and the population size of mutant HC1-07prtR2 was significantly lower than that of the wild type and the complemented strain HC107prtR2-1.

Because HC1-07 was originally isolated from the phyllosphere, we also determined its ability to colonize and survive in the rhizosphere of wheat in the field. Under field conditions, the population sizes of $\mathrm{HC} 1-07$ on the roots at the first sampling time ( 3 weeks after planting) were $10^{8} \mathrm{CFU} \mathrm{g^{-1 }}$ fresh root weight and declined thereafter to $\approx 10^{7} \mathrm{CFU} \mathrm{g}^{-1}$ fresh root weight over a period of 16 weeks (Fig. 2B).

Impact of viscB and prtR mutations on biocontrol of takeall and Rhizoctonia root rot. The capacity of $P$. fluorescens HC1-07 and its isogenic mutants and complemented mutant derivatives to inhibit hyphal growth of $G$. graminis var. tritici and $R$. solani was first assessed in vitro. The wild-type HC1-07 demonstrated strong inhibition of three isolates of $G$. graminis var. tritici and of $R$. solani AG-8 (Table 6; Supplemental Figure 4). In contrast, CLP-deficient mutants HC1-07viscB and HC107 prtR2 were greatly reduced in ability to inhibit the growth of the pathogens, and complemented derivatives of both mutants regained the ability.

The wild-type HC1-07, its CLP-deficient mutants HC107viscB and HC1-07prtR2, and complemented mutants were also tested for the ability to suppress $G$. graminis var. tritici and $R$.
A
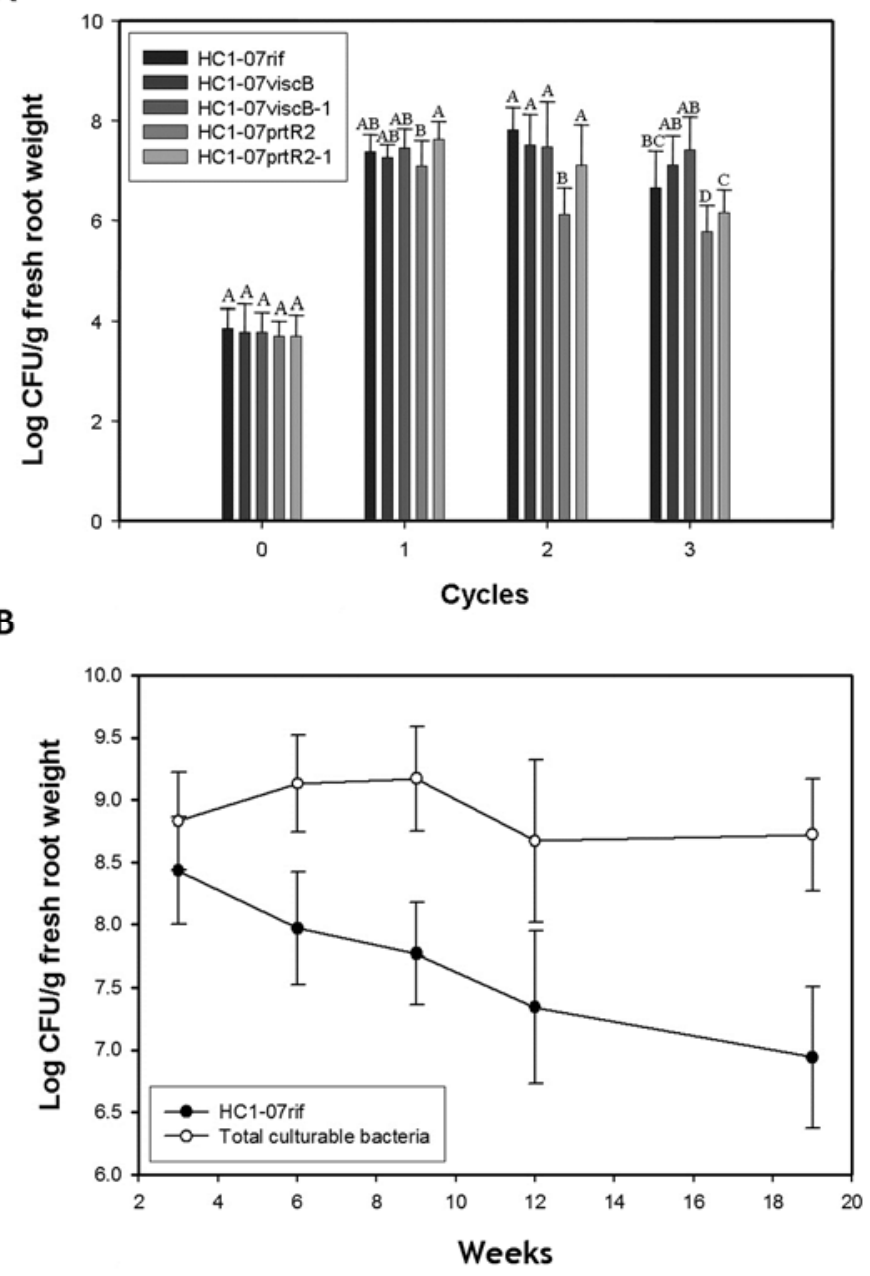

Fig. 2. A, Root colonization by HC1-07rif, cyclic lipopeptide-deficient mutants HC1-07viscB and HC1-07prtR2, and complemented mutants HC107viscB-1 and HC1-07prtR2-1 in a wheat cycling experiment conducted under controlled conditions in a growth chamber. Bacteria were introduced into the soil to give approximately $10^{4} \mathrm{CFU} g$ soil ${ }^{-1}$. Cycle 0 shows population sizes of each strain in the soil at the time of planting. Each cycle of wheat growth lasted 2 weeks, at which time the wheat was harvested and another cycle of wheat was then planted. Bars indicate means and error bars indicate standard deviations. The same letter above bars for the same cycle indicates that the means are not significantly different $(P=0.05)$ according to the Fisher's protected least-significant-difference test (unless indicated otherwise). B, Root colonization of spring wheat ('Louise') in the field at Pullman, WA by strain HC1-07rif. Seed were treated with HC1-07rif at approximately $10^{6}$ $\mathrm{CFU} / \mathrm{seed}$, population sizes were determined every 3 weeks after planting, and the last sample was taken at week 19. Error bars indicate standard deviations.

TABLE 4. Comparison of the putative nonribosomal peptide synthetase (NRPS) ViscB of Pseudomonas fluorescens HC1-07 to similar protein sequences from other Pseudomonas spp.

\begin{tabular}{llccc}
\hline Organism & Gene function & NCBI accession number & Blastp E-value & Identity $(\%)$ \\
\hline P. fluorescens SBW25 & Putative NRPS & YP002872142.1 & 0.0 & 90 \\
P. synxantha BG33R & NRPS MassC & ZP10142895.1 & 0.0 & 81 \\
Pseudomonas sp. Ag1 & Putative NRPS & ZP10143315.1 & 0.0 & 79 \\
P. fluorescens SS101 & Putative NRPS & ABH06369.2 & 0.0 & 79 \\
\hline
\end{tabular}

${ }^{\mathrm{z}}$ National Center for Biotechnology Information.

TABLE 5. Comparison of the regulatory protein PrtR of Pseudomonas fluorescens HC1-07 to similar protein sequences from other Pseudomonas spp.

\begin{tabular}{|c|c|c|c|c|c|}
\hline Species & Strain & Gene function & NCBI accession number ${ }^{2}$ & Blastp E-value & Identity (\%) \\
\hline P. fluorescens & SBW25 & Putative transmembrane regulator & YP002873451.1 & $5 e-148$ & 94 \\
\hline P. fluorescens & LS107d2 & Transmembrane regulator & AAF81075.1 & $2 \mathrm{e}-143$ & 89 \\
\hline P. extremaunstralis & $14.3 \mathrm{~b}$ & Transcriptional regulator & ZP101437425.1 & $2 e-142$ & 89 \\
\hline
\end{tabular}

${ }^{\mathrm{z}}$ National Center for Biotechnology Information. 
solani AG-8 under controlled conditions. Strain HC1-07 applied as a seed treatment provided significant suppression of take-all and Rhizoctonia root rot based on root disease ratings when compared with the nontreated controls in both raw and pasteurized soil (Table 7). When compared with the wild-type parent, the two CLP-deficient mutants provided significantly less suppression $(P=0.05)$ of take-all based on root disease ratings. However, the mutants did not lose all of their biocontrol activity. Genetically complemented mutants regained the ability to control take-all (Table 7) to the same level as the wild type. The results were similar when tests were done in both raw and pasteurized soil. In contrast, these strains responded differently against Rhizoctonia root rot. Mutant HC1-07viscB but not HC1-07prtR2 suppressed Rhizoctonia root rot significantly less than the wild type in raw and pasteurized soil (Table 7). Only in pasteurized soil did the genetically complemented strain HC1-07viscB-1 show fully restored biocontrol activity (Table 7). Thus, the viscosin-like CLP appeared to be a more important determinant of disease suppression against take-all than Rhizoctonia root rot.

\section{DISCUSSION}

In this study, we demonstrated the involvement of a CLP from P. fluorescens stain HC1-07 in the biocontrol of take-all and Rhizoctonia root rot, two economically important diseases of wheat. Results of this work revealed that $P$. fluorescens HC1-07 produces a CLP with molecular structure similar to that of viscosin. Viscosin is a CLP that was first isolated from $P$. viscosa (30) and was later implicated as a key metabolite responsible for the ability of Pseudomonas spp. to control the brown blotch disease of mushrooms caused by $P$. tolaasii (56). Three lines of evidence suggested that the viscosin-like CLP is an important component of the biocontrol activity of strain HC1-07. First, the addition of CLP extracted from HC1-07 to the growth medium even at a concentration of $10 \mu \mathrm{g} \mathrm{ml}^{-1}$ inhibited the hyphal growth of both $G$. graminis var. tritici and $R$. solani AG-8. Second, both CLP-nonproducing mutants $\mathrm{HC} 1-07$ viscB and HC1-07prtR2 were significantly less effective in biocontrol of take-all than HC1-07, and $\mathrm{HC1}-07$ viscB was reduced in activity against Rhizoctonia root rot. Finally, genetic complementation of the mutants HC107viscB and $\mathrm{HC1}-07$ prtR2 restored their biocontrol activity to wild-type levels. CLP production is only one mechanism of suppression in strain HC1-07 because the mutants still retained significant biocontrol activity compared with the nontreated controls. In addition, the viscosin-like CLP appears to be a much more important determinant of disease suppression against takeall than Rhizoctonia root rot because the mutant HC1-07prtR2 was not significantly different from the wild type in Rhizoctonia spp. control. This is not surprising given that both extracted CLP

TABLE 6. In vitro inhibition of Gaeumannomyces graminis var. tritici and Rhizoctonia solani by the wild-type HC1-07, cyclic lipopeptide-deficient mutants, and complemented mutant derivatives

\begin{tabular}{lcccc}
\hline & \multicolumn{3}{c}{ Relative inhibition of radial hyphal growth $(\%)^{\mathrm{z}}$} \\
\cline { 2 - 4 } Treatment & \multicolumn{3}{c}{ G. graminis var. tritici } & \\
\cline { 2 - 4 } & LD5 & ARS-A1 & R3-111a-1 & R. solani \\
\hline HC1-07rif & $56.1 \mathrm{~A}$ & $56.3 \mathrm{~A}$ & $56.8 \mathrm{~A}$ & $46.1 \mathrm{~B}$ \\
HC1-07viscB & $15.3 \mathrm{~B}$ & $5.8 \mathrm{C}$ & $12.5 \mathrm{C}$ & $8.7 \mathrm{C}$ \\
HC1-07viscB-1 & $50.1 \mathrm{~A}$ & $47.2 \mathrm{~B}$ & $49.9 \mathrm{AB}$ & $54.8 \mathrm{~A}$ \\
HC1-07prtR2 & $10.1 \mathrm{~B}$ & $16.7 \mathrm{C}$ & $8.1 \mathrm{C}$ & $5.7 \mathrm{C}$ \\
HC1-07prtR2-1 & 47.9 A & $53.3 \mathrm{AB}$ & $44.9 \mathrm{~B}$ & $50.8 \mathrm{AB}$ \\
\hline
\end{tabular}

${ }^{\mathrm{z}}$ Data represent the mean from three replicate plates. Means in the same column followed by the same letter are not significantly different at $P=0.05$ according to Fisher's protected least significant difference test. Distance between the bacterial colony and the edge of the mycelium on one-fifthstrength potato dextrose agar compared with that on the control plate (not inoculated with bacteria). and $\mathrm{HC1-07}$ showed greater inhibition of G. graminis var. tritici than $R$. solani in vitro. In addition, these two organisms belong to different classes of fungi (Ascomycetes and Basidiomycetes, respectively). Furthermore, it is also known that G. graminis var. tritici is especially sensitive to many different mechanisms of biocontrol compared with other soilborne fungi (63).

In order to identify genes involved in the production of the viscosin-like CLP in HC1-07, we subjected this strain to plasposon mutagenesis and characterized genetic loci affected in the two resultant CLP-deficient mutants. In the first mutant, HC1$07 \mathrm{viscB}$, the mutation site was located in the gene similar to $v i s c B$ of $P$. fluorescens SBW25, which encodes for ViscB, a NRPS. In SBW25 (from the phyllosphere of sugar beet in the United Kingdom), $v i s c B$ is one of the three key genes (viscA, viscB, and $v i s c C$ ) in the synthesis of viscosin (11). In the second mutant, the mutation site was found in the gene prtR, which encodes a transmembrane regulator PrtR. prtR is translationally coupled to an upstream gene, prtI, which encodes an ECF (extracytoplasmic function) $\sigma$ factor. PrtR was reported to be required for protease expression at 29 but not $23^{\circ} \mathrm{C}$ in Pseudomonas LS107d2 (5). We found that mutating the prtR gene also resulted in the loss of protease activity but at both 23 and $29^{\circ} \mathrm{C}$; thus, protease production in the mutant HC1-07prtR was not related to the temperature. Interestingly, prtR in $\mathrm{HC} 1-07$ not only plays a role in protease production but also functions in regulation of the production of the viscosin-like CLP. De Bruijn and Raaijmakers (12) reported a similar phenomenon in P. fluorescens SS101, where the serine protease ClpP regulates the biosynthesis of the CLP massetolides, which are involved in swarming motility, biofilm formation, and antimicrobial activity.

CLP production is known to play an important role in surface motility and biofilm formation $(11,52)$. Our soft agar assays showed that the mutants HC1-07viscB and HC1-07prtR2 were completely impaired in surface motility, a result also reported for the viscosin-deficient mutants of $P$. fluorescens SBW25 (11). In addition, microtiter plate assays showed that the two mutants produced significantly less biofilm than the wild-type HC1-07 and the complemented mutants. Different CLPs, including arthrofactin and putisolvin, have been reported to influence biofilm formation; however, the way that this occurs is still unclear but their impact on cell surface hydrophobicity may be important in this process. Hydrophobic interactions and surface-active compounds, such as CLPs, are thought to play a role in the adherence of cells to surfaces (53).

The function of CLPs in colonization and dispersal of bacteria in natural habitats is still emerging but apparently varies by plant species and ecological niche. Tran et al. (59) showed that the

TABLE 7. Severity ratings of take-all and Rhizoctonia root rot disease in wheat inoculated with $\mathrm{HC1-07}$ wild-type, cyclic lipopeptide-deficient mutants, and complemented mutants as seed treatments

\begin{tabular}{lccccc}
\hline & \multicolumn{4}{c}{ Disease severity ratingz } \\
\cline { 2 - 3 } & \multicolumn{2}{c}{ Take-all } & & Rhizoctonia root rot \\
\cline { 2 - 3 } \cline { 5 - 6 } Treatment & Pasteurized & Raw & & Pasteurized & Raw \\
\hline HC1-07rif & $2.8 \mathrm{D}$ & $3.2 \mathrm{C}$ & & $2.5 \mathrm{C}$ & $2.4 \mathrm{C}$ \\
HC1-07viscB & $3.5 \mathrm{C}$ & $3.6 \mathrm{~B}$ & & $3.3 \mathrm{~B}$ & $2.9 \mathrm{~B}$ \\
HC1-07viscB-1 & $3.1 \mathrm{D}$ & $3.4 \mathrm{C}$ & & $2.6 \mathrm{C}$ & $2.6 \mathrm{BC}$ \\
HC1-07prtR2 & $3.9 \mathrm{~B}$ & $3.7 \mathrm{~B}$ & & $2.8 \mathrm{C}$ & $2.8 \mathrm{BC}$ \\
HC1-07prtR2-1 & $3.0 \mathrm{D}$ & $3.3 \mathrm{C}$ & & $2.6 \mathrm{C}$ & $2.5 \mathrm{BC}$ \\
CK+pathogen & 4.4 A & $3.9 \mathrm{~A}$ & & $4.3 \mathrm{~A}$ & $4.3 \mathrm{~A}$ \\
CK+MC+pathogen & 4.1 AB & 4.1 A & & $4.1 \mathrm{~A}$ & $4.2 \mathrm{~A}$ \\
\hline
\end{tabular}

${ }^{y} \mathrm{CK}$, a nontreated control; $\mathrm{CK}+\mathrm{MC}$, seed treated with methyl cellulose; bacteria were applied to the seed with methyl cellulose at a dose of $10^{7} \mathrm{CFU}$ seed $^{-1}$.

${ }^{\mathrm{z}}$ Ratings represent the mean disease severity on 90 replicate plants on a scale of 0 to 8 , where $0=$ no disease detected and $8=$ dead plants. Means in the same column followed by the same letter are not significantly different at $P=0.05$ according to the Kruskal-Wallis all-pairwise comparison test. 
wild-type strain $P$. fluorescens SS101, when applied to tomato seed, was more effective in colonizing the root system of tomato seedlings than its massetolide-deficient mutant. Similarly, a viscosin-deficient mutant of $P$. fluorescens strain 5064 was unable to colonize the surface of intact broccoli florets (22). Surfactin and amphisin produced by B. subtilis strain 6031 and Pseudomonas sp. DSS73, respectively, were also shown to be important traits in the colonization of Arabidopsis roots and sugar beet seed $(2,44)$. In contrast, the mass $A$-minus mutant 10.24 was detected at higher populations in the wheat and apple rhizosphere and in soil compared with the wild-type P. fluorescens SS101 at 30 days after the strains were introduced into an orchard soil (41). We found that loss of the ability to produce the viscosin-like CLP had no effect on the ability of $\mathrm{HC} 1-07$ to colonize the wheat rhizosphere in the cycling experiment. The slight loss in rhizosphere competence in mutant $\mathrm{HC} 1-07 \mathrm{prtR} 2$ may be related to loss of other traits that prtR impacts. The cycling experiment is an especially robust assay to test the role of a trait or gene in root colonization because bacteria introduced into the soil must survive, colonize the root, and then recolonize the root again after surviving in the soil.

In conclusion, our study specifically shows that the biocontrol strain P. fluorescens HC1-07 produces a viscosin-like CLP that plays a key role in the suppression of root diseases of wheat but the CLP does not contribute to the rhizosphere competence of the strain. In a broader context, our results add support to an emerging picture that certain biocontrol microorganisms, mechanisms, metabolites, or genes are cosmopolitan in agro-ecosystems worldwide, where they contribute to some level of natural suppression of soilborne and foliar plant diseases.

\section{ACKNOWLEDGMENTS}

This research was supported by Special Fund for Agro-Scientific Research in the Public Interest (200903052 and 201003065), National Natural Science Foundation of China (31171809 and 30971956), and Chinese Scholarship of Research Plan for Joint Educational Ph.D. Program. Mention of trade names or commercial products in this publication is solely for the purpose of providing specific information and does not imply recommendation or endorsement by the United States Department of Agriculture (USDA). USDA is an equal opportunity provider and employer.

\section{LITERATURE CITED}

1. Ausubel., F, M., Brent, R., Kingston, R. E., Moore., D, D., Seidman, J. G., Smith, J. A., and Struhl, K. 2002. Short Protocols in Molecular Biology, 5th ed. John Wiley \& Sons, New York.

2. Bais, H. P., Fall, R., and Vivanco, J. M. 2004. Biocontrol of Bacillus subtilis against infection of Arabidopsis roots by Pseudomonas syringae is facilitated by biofilm formation and surfactin production. Plant Physiol. 134:307-319.

3. Bender, C. L., and Scholz-Schroeder, B. K. 2004. New insights into the biosynthesis, mode of action, and regulation of syringomycin, syringopeptin and coronatine. Pages 125-158 in: Pseudomonas, Vol. 2, Virulence and Gene Regulation. J.-L. Ramos, ed. Kluwer Academic/Plenum Publishers, New York.

4. Braun, P. G., Hildebrand, P. D., Ells, T. C., and Kobayashi, D. Y. 2001. Evidence and characterization of a gene cluster required for the production of viscosin, a lipopeptide biosurfactant, by a strain of Pseudomonas fluorescens. Can. J. Microbiol. 47:294-301.

5. Burger, M., Woods, R. G., McCarthy, C., and Beacham, I. R. 2000. Temperature regulation of protease in Pseudomonas fluorescens LS107d2 by an ECF sigma factor and a transmembrane activator. Microbiology 146:3149-3155.

6. Cook, R. J. 2003. Take-all of wheat. Physiol. Mol. Plant Pathol. 62:73-86.

7. Cook, R. J., Weller, D. M., Youssef El-Banna, A., Vakoch, D., and Zhang, H. 2002. Yield responses of direct-seeded wheat to rhizobacteria and fungicide seed treatments. Plant Dis. 86:780-784.

8. D'aes, J., De Meyer, K., Pauwelyn, E., and Höfte, M. 2010. Biosurfactants in plant-Pseudomonas interactions and their importance to biocontrol. Environ. Microbiol. Rep. 2:359-372.
9. D'aes, J., Hua, G. K., De Maeyer, K., Pannecoucque, J., Forrez, I., Ongena, M., Dietrich, L. E., Thomashow, L. S., Mavrodi, D. V., and Höfte, M. 2011. Biological control of Rhizoctonia root rot on bean by phenazine and cyclic lipopeptide producing Pseudomonas CMR12a. Phytopathology 101:996-1004.

10. De Bruijn, I., de Kock, M. J. D., de Waard, P., van Beek, T. A., and Raaijmakers, J. M. 2008. Massetolide A biosynthesis in Pseudomonas fluorescens. J. Bacteriol. 190:2777-2789.

11. De Bruijn, I., de Kock, M. J. D., Yang, M., de Waard, P., van Beek, T. A., and Raaijmakers, J. M. 2007. Genome-based discovery, structure prediction and functional analysis of cyclic lipopeptide antibiotics in Pseudomonas species. Mol. Microbiol. 63:417-428.

12. De Bruijn, I., and Raaijmakers, J. M. 2009. Diversity and functional analysis of LuxR-type transcriptional regulators in cyclic lipopeptide biosynthesis in Pseudomonas fluorescens. Appl. Environ. Microbiol. 75:4753-4761.

13. Dennis, J. J., and Zylstra, G. J. 1998. Plasposons: Modular self-cloning minitransposon derivatives for rapid genetic analysis of gram-negative bacterial genomes. Appl. Environ. Microbiol. 64:2710-2715.

14. De Souza, J. T., de Boer, M., de Waard, P., van Beek, T. A., and Raaijmakers, J. M. 2003. Biochemical, genetic, and zoosporicidal properties of cyclic lipopeptide surfactants produced by Pseudomonas fluorescens. Appl. Environ. Microbiol. 69:7161-7172.

15. Dubern, J. F., Coppoolse, E. R., Stiekema, W. J., and Bloemberg, F. V. 2008. Genetic and functional characterization of the gene cluster directing the biosynthesis of putisolvin I and II in Pseudomonas putida strain PCL1445. Microbiology 154:2070-2083.

16. Dubern, J. F., Lagendijk, E. L., Lugtenberg, B. J. J., and Bloemberg, G. V. 2005. The heat shock genes dnaK, dnaJ, and grpE are involved in regulation of putisolvin biosynthesis in Pseudomonas putida PCL1445. J. Bacteriol. 187:5967-5976.

17. Dubern, J. F., Lugtenberg, B. J. J., and Bloemberg, G. V. 2006. The ppuI$r s a L-p p u R$ quorum-sensing system regulates biofilm formation of Pseudomonas putida PCL1445 by controlling biosynthesis of the cyclic lipopeptides putisolvins I and II. J. Bacteriol. 188:2898-2906.

18. Finking, R., and Marahiel, M. A. 2004. Biosynthesis of non-ribosomal peptides. Annu. Rev. Microbiol. 58:453-488.

19. Fogliano, V., Ballio, A., Gallo, M., Woo, S., Scala, F., and Lorito, M. 2002. Pseudomonas lipodepsipeptides and fungal cell wall-degrading enzymes act synergistically in biological control. Mol. Plant-Microbe Interact. 15:323-333.

20. Haas, D., and Défago, G. 2005. Biological control of soil-borne pathogens by fluorescent pseudomonads. Nat. Rev. Microbiol. 3:307-319.

21. Haas, D., and Keel, C. 2003. Regulation of antibiotic production in rootcolonizing Pseudomonas spp. and relevance for biological control of plant diseases. Annu. Rev. Phytopathol. 41:117-153.

22. Hildebrand, P. D., Braun, P. G., McRae, K. B., and Lu, X. 1998. Role of the biosurfactant viscosin in broccoli head rot caused by a pectolytic strain of Pseudomonas fluorescens. Can. J. Plant Pathol. 20:296-303.

23. Hong, J., Miao, R., Zhao, C. M., Jiang, J., Tang, H. W., Guo, Z. J., and Zhu, L. G. 2006. Mass spectrometry assisted assignments of binding and cleavage sites of copper(II) and platinum(II) complexes towards oxidized insulin B chain. J. Mass Spectrom. 41:1061-1072.

24. Howell, C. R., and Stipanovic, R. D. 1979. Control of Rhizoctonia solani on cotton seedlings with Pseudomonas fluorescens and with an antibiotic produced by the bacterium. Phytopathology 69:480-482.

25. Howell, C. R., and Stipanovic, R. D. 1980. Suppression of Pythium ultimum-induced damping-off of cotton seedlings by Pseudomonas fluorescens and its antibiotic, pyoluteorin. Phytopathology 70:712-715.

26. Huang, Z. Y., Bonsall, R. F., Mavrodi, D. V., Weller, D. M., and Thomashow, L. S. 2004. Transformation of Pseudomonas fluorescens with genes for biosynthesis of phenazine-1-carboxylic acid improves biocontrol of Rhizoctonia root rot and in situ antibiotic production. FEMS Microbiol. Ecol. 49:243-251.

27. Kim, B. S., Lee, J. Y., and Hwang, B. K. 2000. In vitro control and in vitro antifungal activity of rhamnolipid $\mathrm{B}$, a glycilipid antibiotic, against Phytophthora capsici and Colletotrichum orbiculare. Pest Manage. Sci. 56:1029-1035

28. Kim, D. S., Cook, R. J., and Weller, D. M. 1997. Bacillus sp. L324-92 for biological control of three root diseases of wheat grown with reduced tillage. Phytopathology 87:551-558.

29. King, E. O., Ward, M. K., and Raney, D. E. 1954. Two simple media for the demonstration of pyocyanin and fluorescein. J. Lab. Clin. Med. 44:301-307.

30. Kochi, M., Weiss, D. W., Pugh, L., and Groupe, V. 1951. Viscosin, a new antibiotic. Bacteriol. Proc. 1:29-30.

31. Kwak, Y. S., Bakker, P. A. H. M., Glandorf, D. C. M., Rice, J. T., Paulitz, T. C., and Weller, D. M. 2009. Diversity, virulence, and 2,4-diacetylphloroglucinol sensitivity of Gaeumannomyces graminis var. tritici isolates from Washington State. Phytopathology 99:472-479. 
32. Kwak, Y. S., Bonsall, R. F., Okubara, P. A., Paulitz, T. C., Thomashow, L. S., and Weller, D. M. 2012. Factors impacting the activity of 2,4diacetylphloroglucinol-producing Pseudomonas fluorescens against takeall of wheat. Soil Biol. Biochem. 54:48-56.

33. Landa, B. B., de Werd, H. A., McSpadden Gardener, B. B., and Weller, D. M. 2002. Comparison of three methods for monitoring populations of different genotypes of 2,4-diacetylphloroglucinol-producing Pseudomonas fluorescens in the rhizosphere. Phytopathology 92:129-137.

34. Lawrence, R. C., Fryer, T. F., and Reiter, B. 1967. Rapid method for the quantitative estimation of microbial lipases. Nature 213:1264-1265.

35. Lugtenberg, B., and Kamilova, F., 2009. Plant-growth-promoting rhizobacteria. Annu. Rev. Microbiol. 63:541-556.

36. MacNish, G. C. 1988. Changes in take-all (Gaeumannomyces graminis var. tritici), Rhizoctonia root rot (Rhizoctonia solani) and soil $\mathrm{pH}$ in continuous wheat with annual applications of nitrogenous fertilizer in Western Australia. Aust. J. Exp. Agric. 28:333-341.

37. Mavrodi, D. V., Blankenfeldt, W., and Thomashow, L. S. 2006. Phenazine compounds in fluorescent Pseudomonas spp. biosynthesis and regulation. Annu. Rev. Phytopathol. 44:417-445.

38. Mavrodi, D. V., Bonsall, R. F., Delaney, S. M., Soule, M. J., Phillips, G., and Thomashow, L. S. 2001. Functional analysis of genes for biosynthesis of pyocyanin and phenazine-1-carboxamide from Pseudomonas aeruginosa PAO1. J. Bacteriol. 183:6454-6465.

39. Mavrodi, O. V., Mavrodi, D. V., Weller, D. M., and Thomashow, L. S. 2006. The role of $d s b A$ in root colonization by Pseudomonas fluorescens Q8r1-96. Microbiology 152:863-872.

40. Mavrodi, O. V., McSpadden Gardener, B. B., Bonsall, R. F., Weller, D. M., and Thomashow, L. S. 2001. Genetic diversity of phlD from 2,4diacetyl-phloroglucinol-producing fluorescent Pseudomonas spp. Phytopathology 91:35-43.

41. Mazzola, M., Zhao, X., Cohen, M. F., and Raaijmakers, J. M. 2007. Cyclic lipopeptide surfactant production by Pseudomonas fluorescens SS101 is not required for suppression of complex Pythium spp. population. Phytopathology 97:1348-1355.

42. McSpadden Gardener, B. B., Mavrodi, D. V., Thomashow, L. S., and Weller, D. M. 2001. A rapid polymerase chain reaction-based assay characterizing rhizosphere populations of 2,4-diacetylphloroglucinolproducing bacteria. Phytopathology 91:44-54.

43. Nielsen, T. H., Christophersen, C., Anthoni, U., and Sorensen, J. 1999. Viscosinamide, a new cyclic depsipeptide with surfactant and antifungal properties produced by Pseudomonas fluorescens DR54. J. Appl. Microbiol. 86:80-90

44. Nielsen, T. H., Nybroe, O., Koch, B., Hansen, M., and Sorensen, J. 2005. Genes involved in cyclic lipopeptide production are important for seed and straw colonization by Pseudomonas sp. strain DSS73. Appl. Environ. Microbiol. 71:4112-4116.

45. Nielsen, T. H., and Sorensen, J. 2003. Production of cyclic lipopeptides by Pseudomonas fluorescens strains in bulk soil and in the sugar beet rhizosphere. Appl. Environ. Microbiol. 69:861-868.

46. O'Toole, G. A., and Kolter, R. 1998. Initiation of biofilm formation in Pseudomonas fluorescens WCS365 proceeds via multiple convergent signaling pathways: A genetic analysis. Mol. Microbiol. 28:449-461.

47. Paulitz, T. C., Okubara, P. A., and Schroeder, K. L. 2009. Integrated control of soilborne pathogens of wheat. Pages 229-245 in: Recent Developments in Management of Plant Diseases. Plant Pathology in the 21st Century, Vol. 1. I. C. U. Gisi, and M. Gullino, eds. Springer, Dordrecht, the Netherlands.

48. Paulitz, T. C., Schroeder, K. L., and Schillinger, W. F. 2010. Soilborne pathogens of cereals in an irrigated cropping system: Effects of tillage, residue management, and crop rotation. Plant Dis. 94:61-68.

49. Paulitz, T. C., Smiley, R. W., and Cook, R. J. 2002. Insights into the prevalence and management of soilborne cereal pathogens under direct seeding in the Pacific Northwest, U.S.A. Can. J. Plant Pathol. 24:416-428.

50. Perneel, M., D’hondt, L., De Maeyer, K., Adiobo, A., Rabaey, K., and Höfte, M. 2008. Phenazines and biosurfactants interact in the biological control of soil-borne diseases caused by Pythium spp. Environ. Microbiol. 10:778-788

51. Pierson, E. A., and Weller, D. M. 1994. Use of mixtures of fluorescent Pseudomonads to suppress take-all and improve the growth of wheat. Phytopathology 84:940-947.

52. Raaijmakers, J. M., de Bruijn, I., and de Kock, M. J. D. 2006. Cyclic lipopeptide production by plant-associated Pseudomonas spp.: Diversity, activity, biosynthesis, and regulation. Mol. Plant-Microbe Interact. 19:699-710.

53. Raaijmakers, J. M., De Bruijn, I., Nybroe, O., and Ongena, M. 2010. Natural functions of lipopeptides from Bacillus and Pseudomonas: more than surfactants and antibiotics. FEMS Microbiol. Rev. 34:1037-1062.

54. Roget, D. K. 1995. Decline in root rot (Rhizoctonia solani AG-8) in wheat in a tillage and rotation experiment at Avon, South Australia. Aust. J. Exp. Agric. 35:1009-1013.

55. Shin, S. H., Lim, Y., Lee, S. E., Yang, N. W., and Rhee, J. H. 2001. CAS agar diffusion assay for the measurement of siderophores in biological fluids. J. Microbiol. Methods 44:89-95.

56. Soler-Rivas, C., Jolivet, S., Arpin, N., Olivier, J. M., and Wichers, H. J. 1999. Biochemical and physiological aspects of brown blotch disease of Agaricus bisporus. FEMS Microbiol. Rev. 23:591-614.

57. Stanghellini, M. E., and Miller, R. M. 1997. Biosurfactants: Their identity and potential efficacy in the biological control of zoosporic plant pathogens. Plant Dis. 81:4-12.

58. Thomashow, L. S., and Weller, D. M. 1988. Role of a phenazine antibiotic from Pseudomonas fluorescens in biological control of Gaeumannomyces graminis var. tritici. J. Bacteriol. 170:3499-3508.

59. Tran, H., Ficke, A., Asiimwe, T., Höfte, M., and Raaijmakers, J. M. 2007. Role of the cyclic lipopeptide massetolide A in biological control of Phytophthora infestans and in colonization of tomato plants by Pseudomonas fluorescens. New Phytol. 175:731-742.

60. Van den Broek, D., Chin-A-Woeng, T. F. C., Eijkemans, K., Mulders, I. H. M., Bloemberg, G. V., and Lugtenberg, B. J. J., 2003. Biocontrol traits of Pseudomonas spp. are regulated by phase variation. Mol. PlantMicrobe Interact. 16:1003-1012.

61. Weller, D. M., and Cook, R. J. 1983. Suppression of take-all of wheat by seed treatments with fluorescent Pseudomonads. Phytopathology 73:463469.

62. Weller, D. M., Landa, B. B., Mavrodi, O. V., Schroeder, K. L., De La Fuente, L., Blouin Bankhead, S., Allende Molar, R., Bonsall, R. F., Mavrodi, D. V., and Thomashow, L. S. 2007. Role of 2,4-diacetyl-phloroglucinol-producing fluorescent Pseudomonas spp. in the defense of plant roots. Plant Biol. 9:4-20.

63. Weller, D. M., Raaijmakers, J. M., Gardener, B. B., and Thomashow, L. S. 2002. Microbial populations responsible for specific soil suppressiveness to plant pathogens. Annu. Rev. Phytopathol. 40:309-348.

64. Yang, M. M., Mavrodi, D. V., Mavrodi, O. V., Bonsall, R. F., Parejko, J. A., Paulitz, T. C., Thomashow, L. S., Yang, H. T., Weller, D. M., and Guo, J. H. 2011. Biological control of take-all by fluorescent Pseudomonas spp. from Chinese wheat fields. Phytopathology 101:1481-1491. 